\title{
AGED YEAST MOTHER CELLS SHOW MARKERS OF APOPTOSIS
}

\author{
Peter Laun*, Alena Pichova, Frank Madeo, Adolf Ellinger, Sepp D. Kohlwein, Kai-Uwe \\ Fröhlich, Ian Dawes, and Michael Breitenbach \\ Institut für Genetik und Allgemeine Biologie, Hellbrunnerstraße 34a, 5020 Salzburg, Austria \\ * Peter.Laun@sbg.ac.at
}

INTRODUCTION. Recently, others and we have shown that genetic and environmental changes that increase the load of yeast cells with ROS (reactive oxygen species) lead to a shortening of the life span of yeast mother cells (1). Deletions of yeast genes coding for the superoxide dismutases or the yeast catalases, as well as changes in atmospheric oxygen concentration and the presence of the physiological antioxidant, glutathione, all had the expected distinct effects on lifespan and pointed to a role of oxygen in the yeast aging process. We have now undertaken a cytological and biochemical characterization of old yeast mother cells prepared by the elutriation method (Molecular Microbiology, in press 2001).

METHODS. We have developed a new method for bulk isolation of old and young yeast cells by elutriation. The method is based on cell size only but yields remarkably pure old and young cell fractions. To characterize these cells, we used standard methods of fluorescence microscopy staining for ROS with dihydrorhodamine123 (DHR). The TUNEL methods as well as staining with annexinV were used to detect markers of apoptosis. Fluorescent staining with Calcofluor White was used to reveal bud scars. Life spans were determined by micromanipulation as described (2).

RESULTS. The fraction containing large cells had a median lifespan of about 3.5 generations. About $10-20 \%$ of these cells were in their last cell cycle. Cells with more than 20 bud scars could be seen. The cytoskeleton was frequently abnormal pointing to loss of cell polarity. The fraction containing small cells in the same strain displayed a median lifespan of about 25 generations identical to the standard lifespan of the strain. The small cells showed just one birth scar and were normal in nuclear morphology.

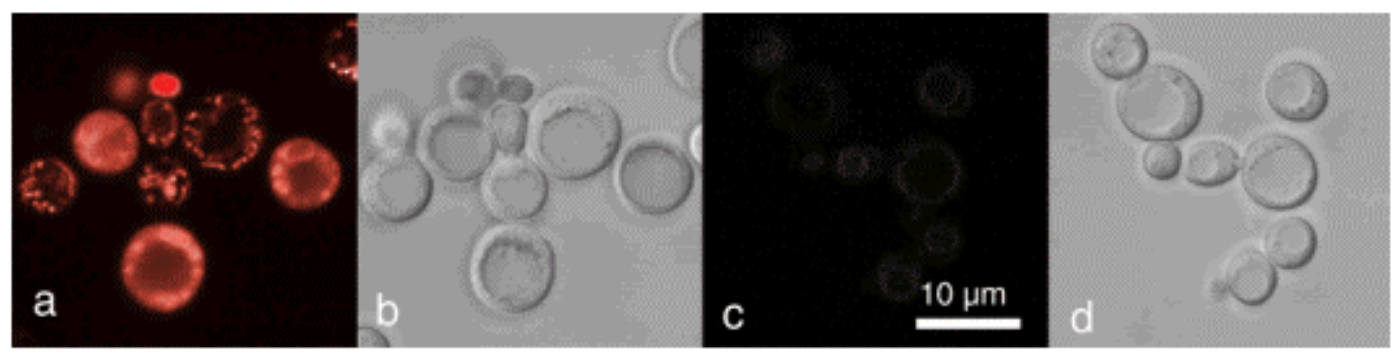


Fig. 1. DHR staining of old $(\mathrm{a}, \mathrm{b})$ and young $(\mathrm{c}, \mathrm{d})$ cells with fluorescence $(\mathrm{a}, \mathrm{c})$ and light microscopy (b,d).

Although the isolated old mother cells are wild type and have not undergone external oxygen stresses, these cells do contain a large amount of oxidizing species (ROS) in their mitochondria (Fig. 1a) while control cells (young cells prepared by the same method) do not (Fig. 1c). Moreover, $10-20 \%$ of the old cells undergo apoptosis as shown by the TUNEL and annexin V tests (3). Again, the control cells did not show apoptotic markers.

DISCUSSION. The present results further support the notion that oxygen toxicity may be a common feature of aging processes in a wide variety of eukaryotic cells. In addition, our finding of a primitive form of apoptosis in aged wild type yeast cells now enables us to further investigate the relationship between aging, oxygen stress and apoptosis in eukaryotes by yeast genetic methods. Recently it was shown that also primary human cells in culture undergo apoptosis during senescence (Jansen-Dürr, pers. comm.).

ACKNOWLEDGEMENT. This work has been supported by grant No. P14574-MOB (FWF Austria; to MB), an ARC IREX grant to IWD and MB and grant GA CR(CZ) GA204/97/0541 to AP.

\section{REFERENCES.}

1. Nestelbacher, R., Laun, P., Vondrakova, D., Pichova, A., Schuller, C., and Breitenbach, M. (2000) Exp. Gerontol. 35, 63-70

2. Pichova, A., Vondrakova, D., and Breitenbach, M. (1997) Can. J. Microbiol. 43, 774781

3. Madeo, F., Frohlich, E., Ligr, M., Grey, M., Sigrist, S.J., Wolf, D.H., and Frohlich, K.U. (1999) J. Cell Biol. 145, 757-767 

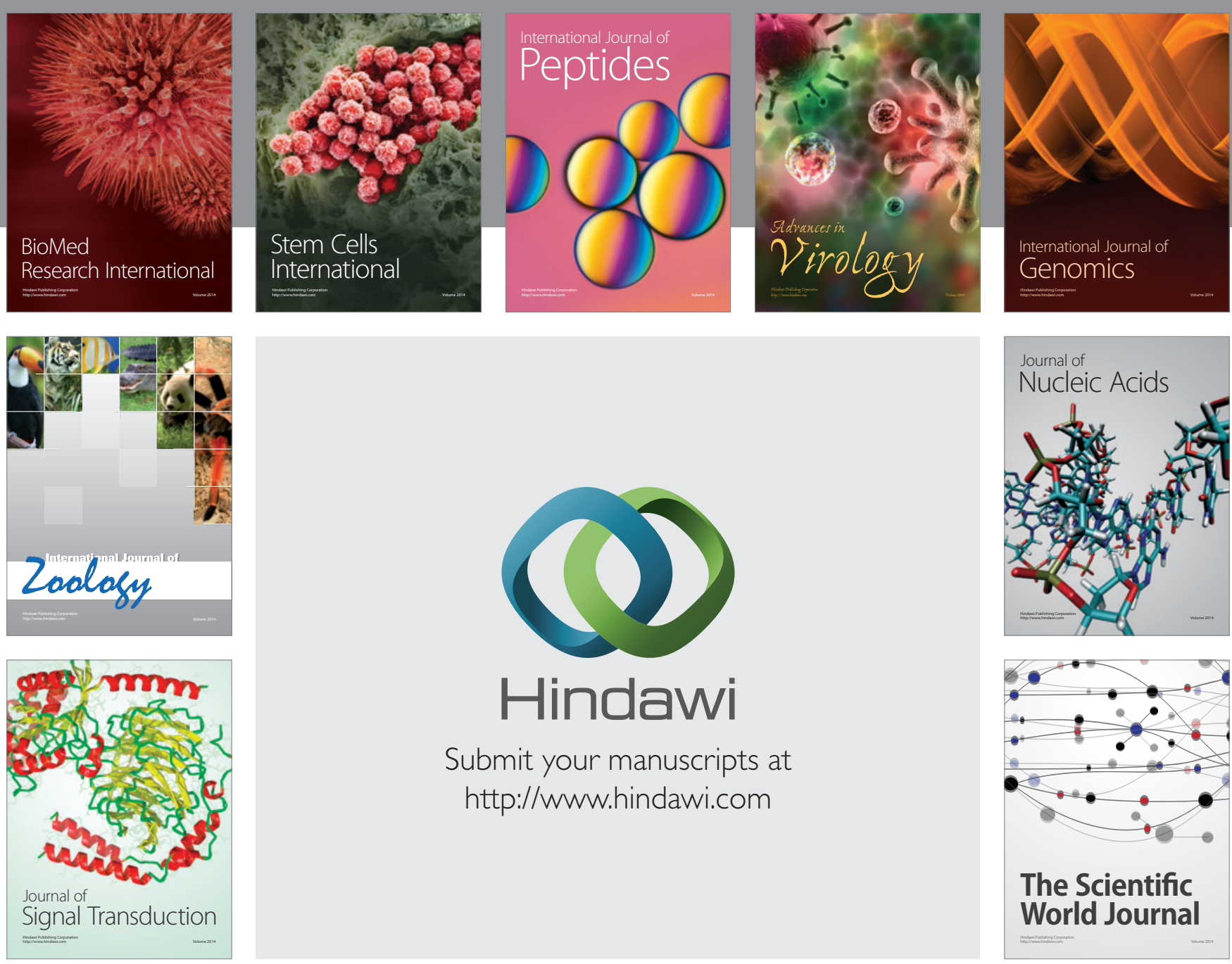

Submit your manuscripts at

http://www.hindawi.com
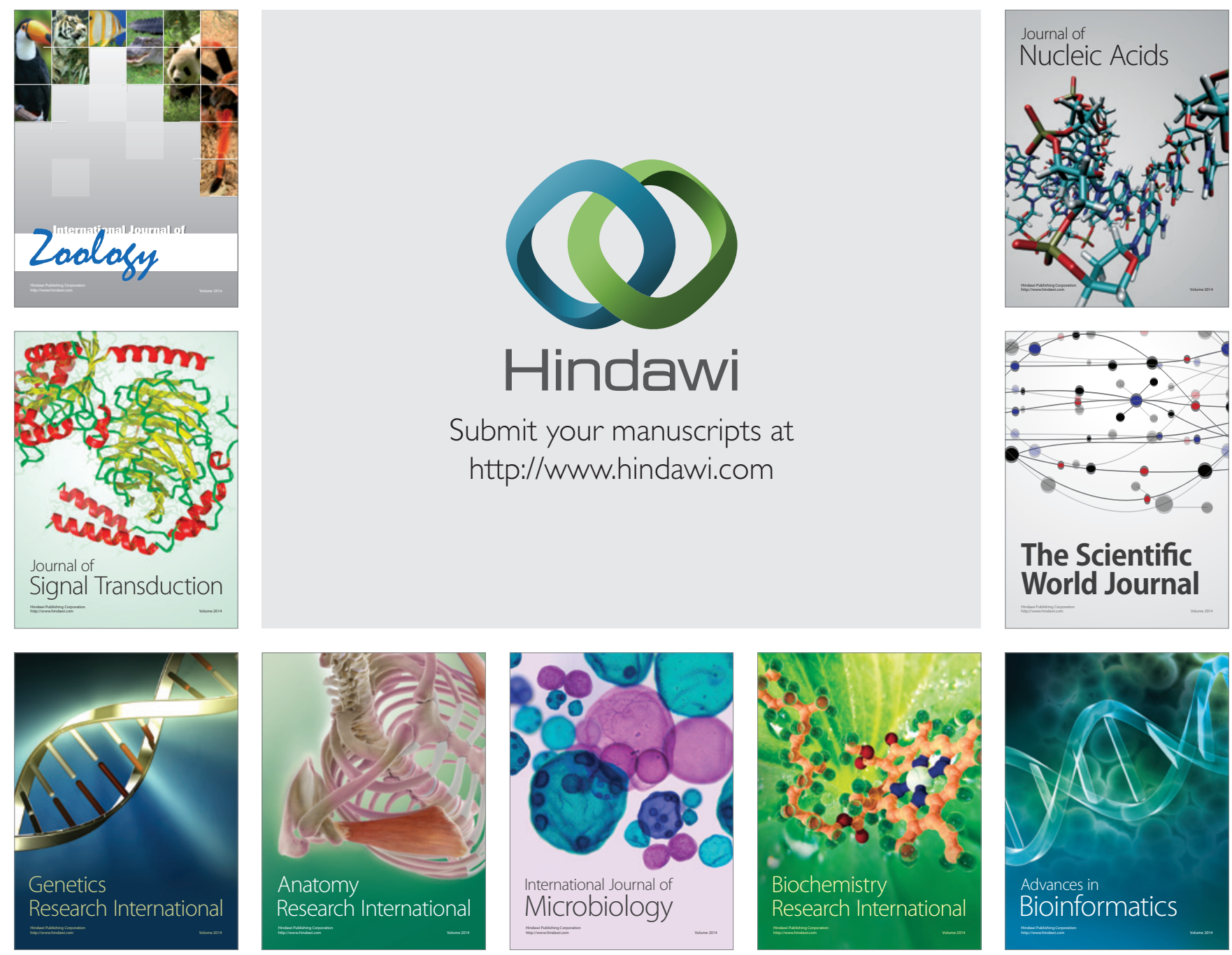

The Scientific World Journal
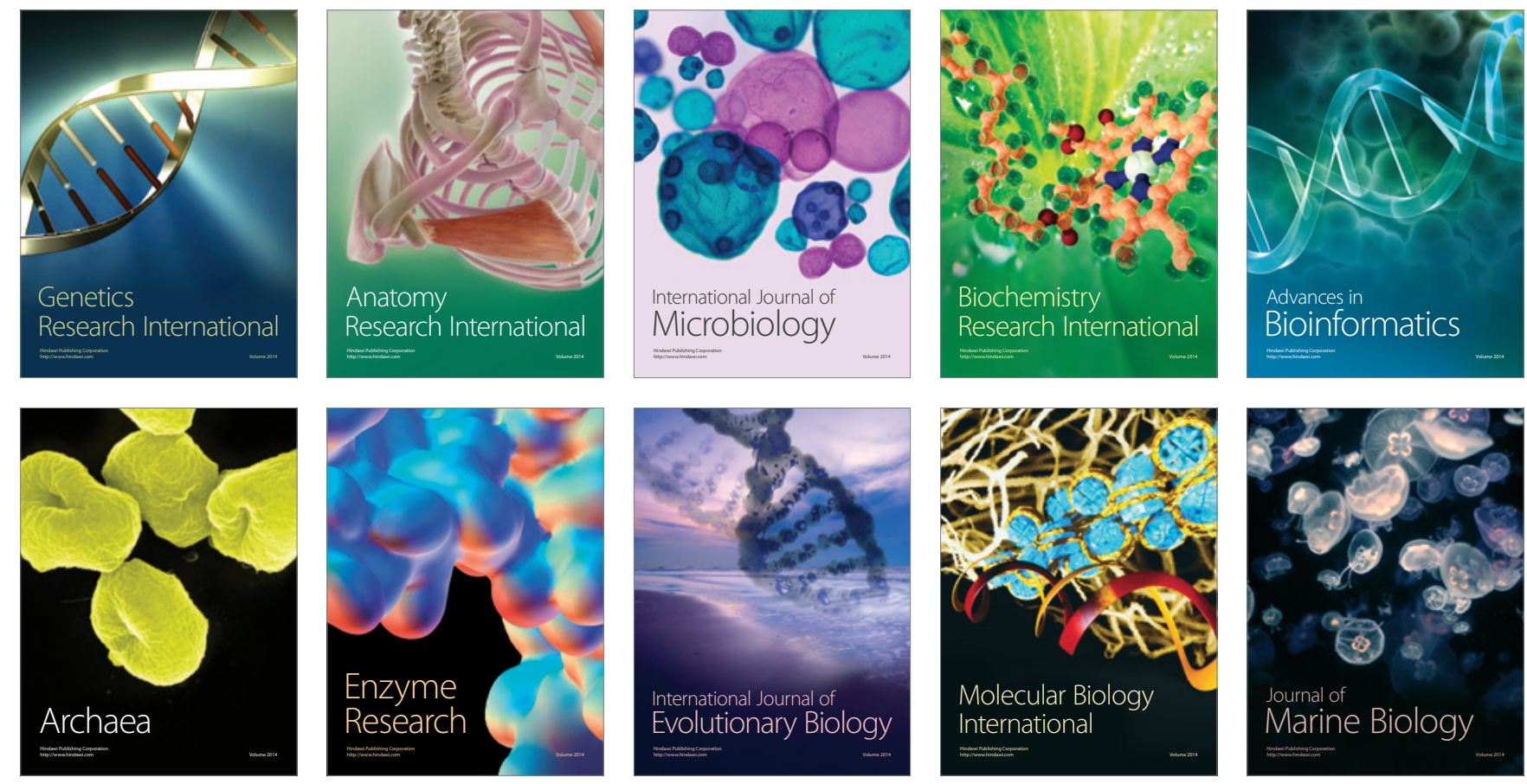